\title{
Development of On-Line Fiber Orientation Control and Practical Using
}

\author{
Michihiro Fujiyama \\ Yatsushiro Mill, Nippon Paper Industries Co., Ltd.
}

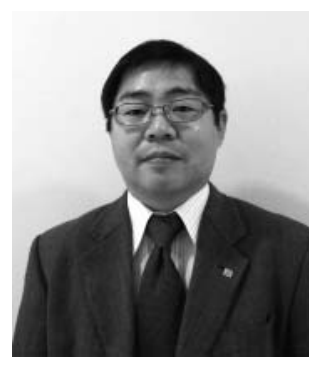

\begin{abstract}
We have succeeded in the development of the online sensor which measured the fiber orientation of the both surfaces of the paper in 1993. And it has been able to help improvement of the curl quality for more than 10 years. In this time we have developed a new online control system of the fiber orientation on both paper surfaces as world's first practical use technology in cooperation with Yokogawa Electric Corporation. In this system the edge flow valves and the slice lip actuators at the headbox are manipulated automatically to minimize the difference of the fiber orientation between both surfaces of the paper continuously. And it can also compensate the disturbance in the basis weight caused by the chang of the slice lip shape.

Now we have been using this automatic control system on an actual copy paper machine since the beginning of 2007 and the curl quality of the copy paper has been improved and stabilized.
\end{abstract}

分類 $: V_{2}$ 紙パルプ工程制御システム, $V_{3}$ 紙パルプ工程計器およびセンサ

\section{1. はじめに}

当社は 1993 年に抄紙機上で走行する紙の表裏の繊維配 向を測定するオンラインセンサの開発に成功した。その後, このオンラインセンサは横河電機株)との共同開発品が製品 化され，1999 年から販売開始されており，長年にわたっ てカール品質の向上に貢献している。今回, 本センサの更 なる有効活用を図り, 世界初の実用化技術として, 横河電 機株)と共同で繊維配向自動制御システムの開発を行った。 これまでも $\mathrm{J} / \mathrm{W}$ やスライスリップの調整により繊維配向 を制御する試みは幾つか報告されているが(6,7),8),9), 本制御 システムは, オンラインセンサからの表裏配向角を制御対 象として, エッジフローバルブとスライスリップアクチュ エータを操作することで, 地合等他の紙質への影響を小さ く, 繊維配向だけを最適に制御することを可能とし た $^{(11), 12,13)}$ 。

本制御システムは，2007 年初頭より PPC 用紙を主に生 産する抄紙機において実運転に供し, PPC 用紙のカール 品質の改善と安定化に効果を発揮している。

\section{2. 抄紙機仕様}

本制御システム開発を行った抄紙機概要とテスト条件に ついて, 表 1 に記す。濃度希釈型ヘッドボックスを備える ハイブリッドタイプの抄紙機であり，フィールドテストは PPC 用紙を製造する通常条件で実施した。

3. 繊維配向とねじれカール

3.1 繊維配向とカール

繊維配向とは, 繊維の配列状態のことを表し紙の強度や

表 1 抄紙機概要とテスト条件

\begin{tabular}{l|l}
\hline ワイヤ幅 & $5,600 \mathrm{~mm}$ \\
\hline ワイヤ形式 & ハイブリッド型ツインワイヤ \\
\hline 坪量制御 & 濃度希釈プロファイル制御 \\
\hline 抄造品種 & $\mathrm{PPC}$ 用紙 \\
\hline 抄速 & $1,000 \mathrm{~m} / \mathrm{min}$ \\
\hline
\end{tabular}




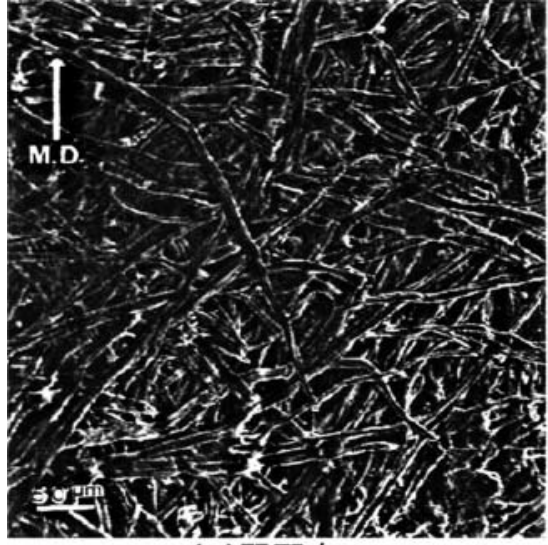

(a)弱配向

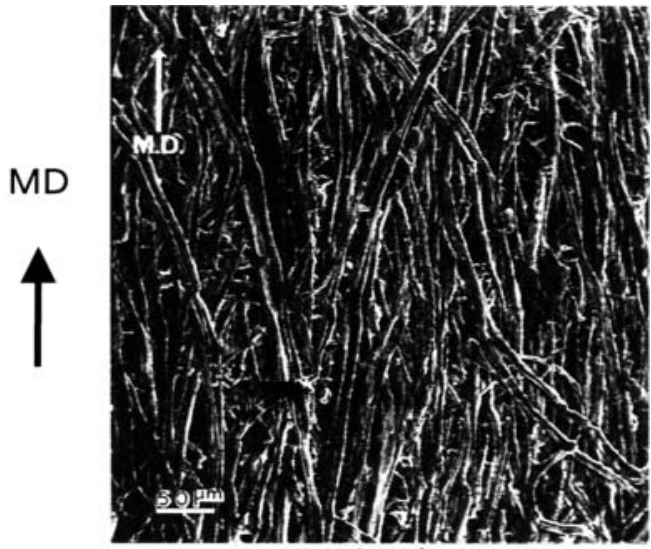

(b)強配向

写真 1 紙表面の繊維配向

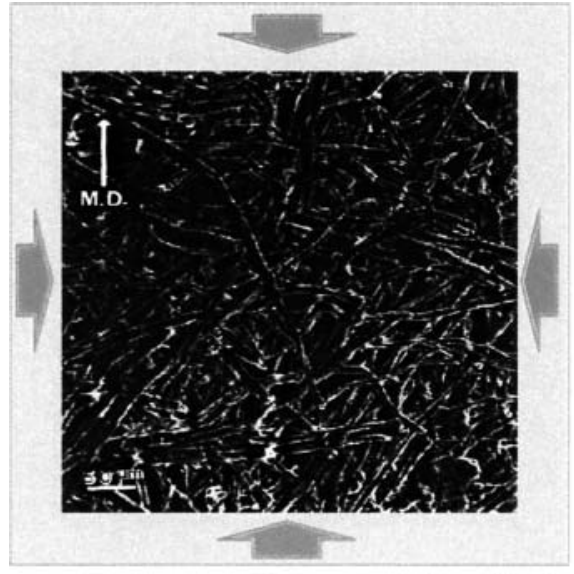

(a)弱配向

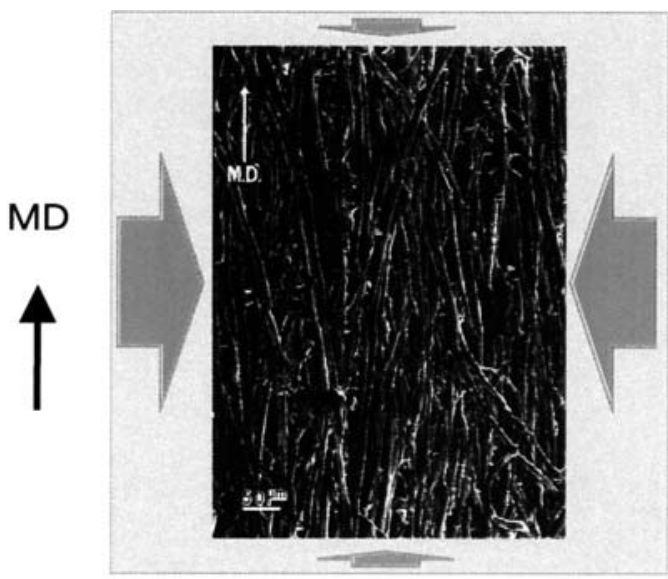

(b)強配向

写真 2 繊維配向による加熱収縮の相違

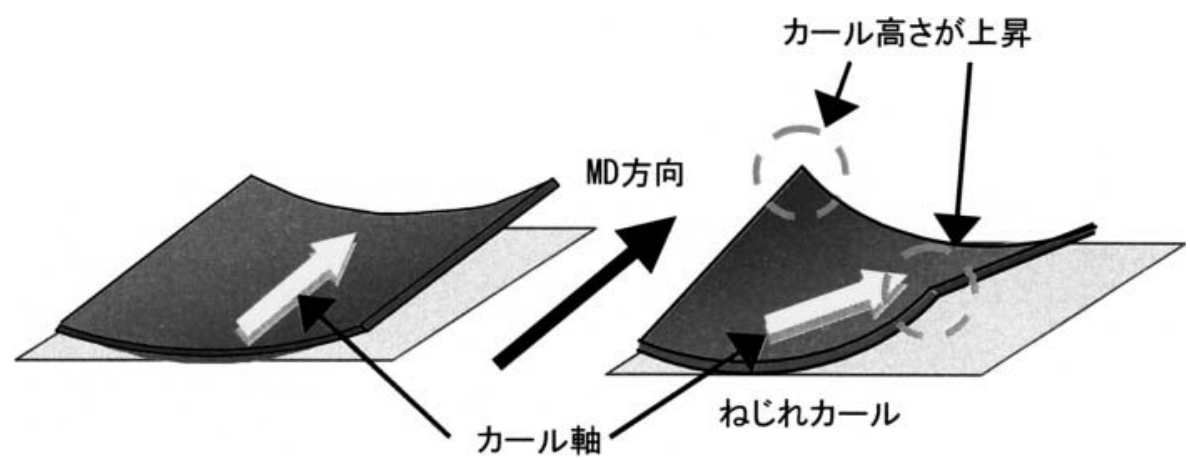

図 1 カール軸の違いによるカール形状

寸法安定性に影響する。写真 1 は紙の表面を電子顕微鏡で 撮影したもので，写真 1 (a) は繊維の配向が弱い場合, 写真 1 （b）は繊維の配向が強く抄紙方向に繊維が並んで いる状態を示している。

この各配向強度の紙を加熱収縮させると, 写真 2 に示す ように縦配向の強い（b）の方が横方向に大きく収縮する。 従って, 図 1 に示すように, 紙のフェルト面（F 面）及び ワイヤ面 (W 面) の表裏における配向強度の差から収縮 率に相違が生じることによりカールが発生する。また，繊
維配向の向きを表す配向角に表裏差があると，ねじれカー ルと呼ばれるカール軸が抄紙方向からずれた形状のカール が発生する。ねじれカールは，一つの角のカールが大きく なるので，PPC用紙においてはコピー機内での紙詰まり やソータでの収容性を悪化させる要因となる。

\section{2 ねじれカールの評価方法}

製造された用紙のねじれカールの評価は，マシンリール でサンプリングを行い，吊りカール法により行った（図 2)。 図中の $\Delta \mathrm{CL}$ は，ねじれカールの大きさを示し，用紙下部 


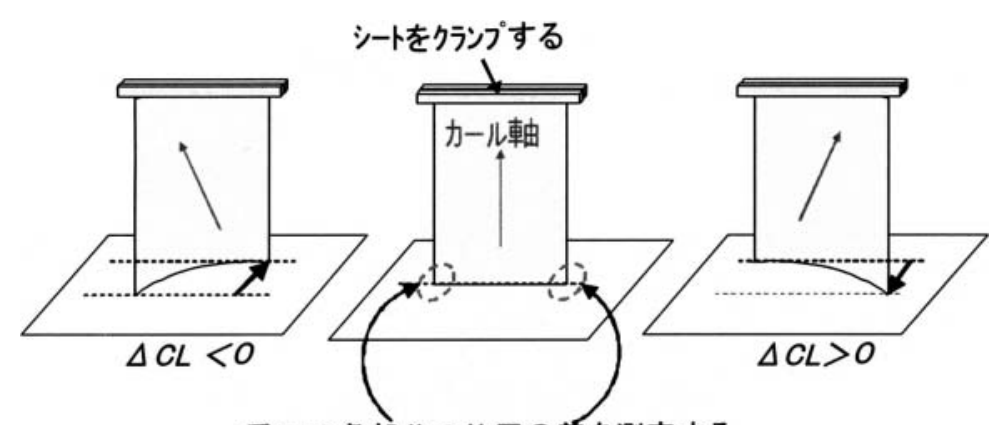

一番下の角部分の位置の差を測定する

（サンプサイズ $297 \mathrm{~mm} \times 210 \mathrm{~mm}$ )

図 2 ねじれカール評価方法概略図

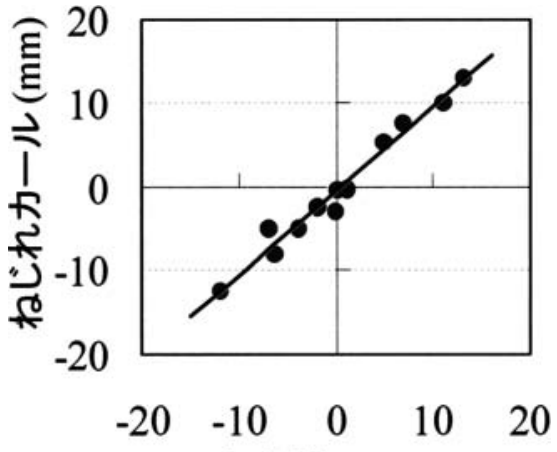

配向角差 (F面-W面)

図 3 配向角差とねじれカール

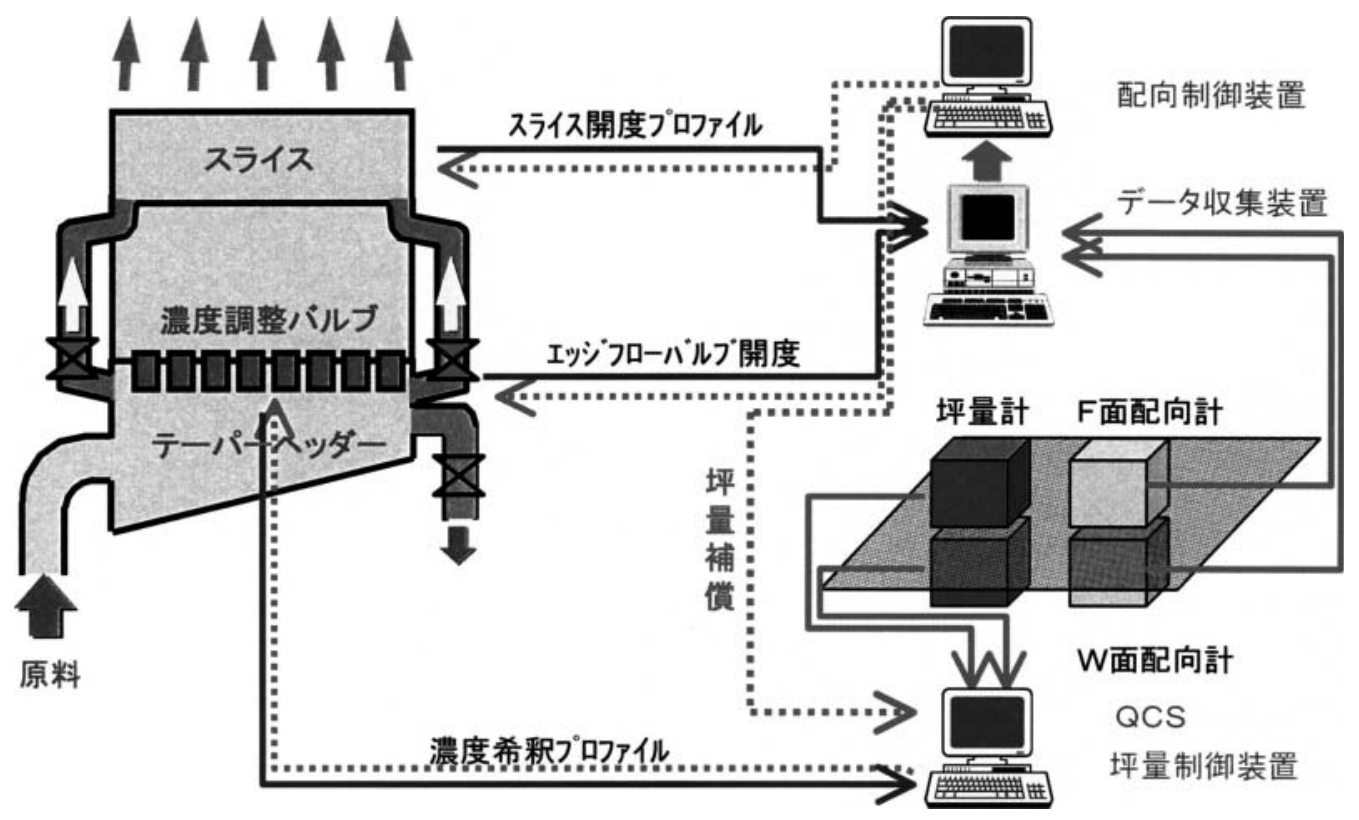

図 4 繊維配向制御システム構成

における $2 つ の$ 角の位置の違いを測定することで得られ， 右側の角が左側と比べ, 手前にカールした場合をプラスと した。

\section{3 繊維配向角差とねじれカールの相関}

図 3 はマシン幅方向でサンプリングした PPC 用紙のね じれカール $(\Delta \mathrm{CL})$ と $\mathrm{F}-\mathrm{W}$ 面の配向角差をオフライン配 向計で測定した結果を示している。両者には非常に高い相 関性が認められ, 配向角差を 0 に近づける程, ねじれカー ルも減少することが確認できる。

\section{4. システム構成}

図 4 に本制御システムの構成図を示す。リールフレーム に F 面及び $\mathrm{W}$ 面のオンライン配向センサを搭載した $\mathrm{QCS}$ に，配向制御用 $\mathrm{PC}$ を追加した構成になっている。QCS で得られた配向角プロファイルを基に, 配向制御装置で演 算を行い, エッジフローバルブ開度とスライスリップ開度 プロファイルを制御している。また，スライスリップ開度 の変化による坪量プロファイルの変動を予測してヘッドボ ックスの濃度調整バルブを調節し補正する坪量非干渉制御
機能を有している。

5. 制御モデルとステップ応答テスト

\section{1 繊維配向角形成メカニズム}

繊維配向角を形成する基本的な要素として，I．ヘッド ボックスから吐出されたジェットの流れ角度と, II . ジェ ットとワイヤとの接触により生じるせん断力（J/W）があ る。つまり，図 5 に示すような速度べクトルをもつジェッ トとワイヤの相互作用により繊維配向角が形成される。こ のとき，ジェット速度がワイヤ速度より大きい，いわゆる “押し”の状態では, 配向角はジェット角度と同じ符号と なるが，逆にワイヤ速度の方が大きい，“引き”の状態で は配向角はジェット角度と逆向きになる。

\section{2 ステップ応答テスト}

図 6 は駆動側のエッジフローバルブを一定量開き，ヘッ ドボックス駆動側の圧力を上昇（流速を上昇）したときの $\mathrm{F}$ 面，W 面の配向角プロファイルを示したものである。 $\mathrm{W}$ 面の配向角は抄紙方向に対し内向き， $\mathrm{F}$ 面は外開きへ と変化し，抄紙機の中央付近まで広範囲にわたり配向角が 
表 2 各アクチュエータ操作による繊維配向の挙動

\begin{tabular}{l|l}
\hline アクチュエータの操作 & \multicolumn{1}{c}{ 繊維配向角の挙動 } \\
\hline エッジフロー流量 & $\begin{array}{l}\text { 配向角プロファイルの中央付近までの全体形状が変化 } \\
\text { 配向角平均值が変化する }\end{array}$ \\
\hline スライスリップ & $\begin{array}{l}\text { リップ操作箇所付近の部分的形状が変化 } \\
\text { 配向角平均值は変化しない }\end{array}$ \\
\hline
\end{tabular}

変化した。

同様に図 7 は幅方向で部分的にスライスリップの開度を 変化したときの，それぞれの配向角プロファイルの変化を 示している。W 面の配向角はジェットの吐出パターンと 同様にスライス開度の広い部分へ向かって内向きに，閉め

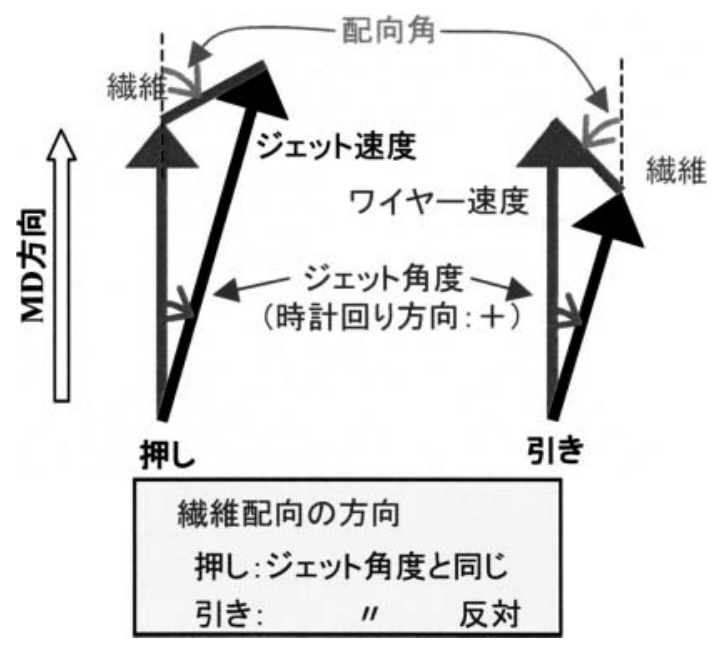

図 5 繊維配向角形成メカニズム
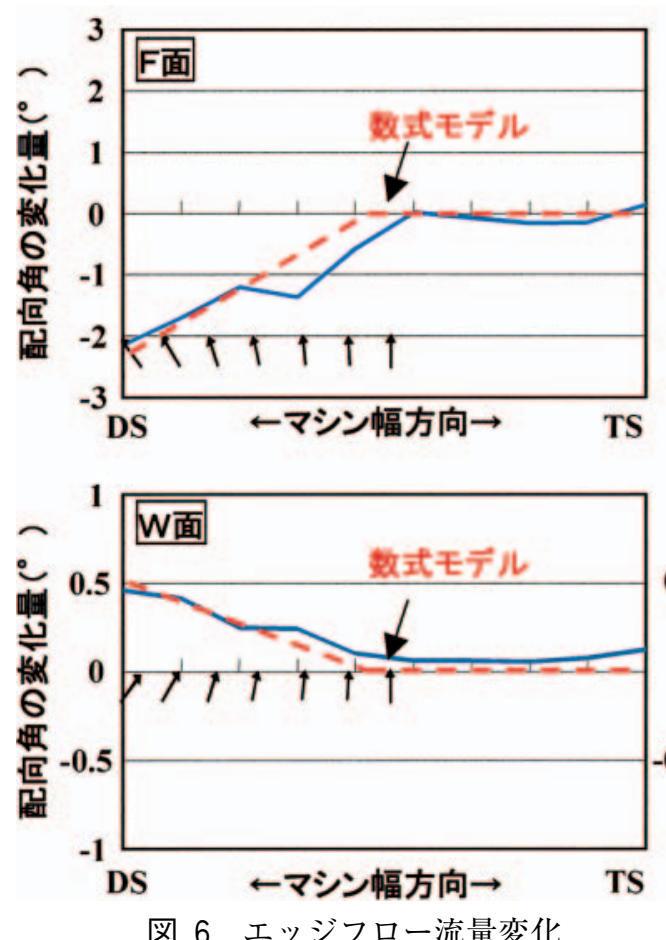

図 6 エッジフロー流量変化
た部分では外開きとなり，両者共に $\mathrm{F}$ 面は逆パターンの プロファイルを示した。これらの結果により，各アクチュ エー夕を使い局所的な範囲や広範囲にわたるジェットの流 れ角度をコントロールすることで，マシン全幅にわたる緎 維配向角の自動制御が可能と考えられた。これらのプロセ ス挙動は流体解析シミュレーションの結果と一致しており, エッジフローバルブとスライスリップ各々を操作した際の 数式モデルを作成して制御に用いた ${ }^{12), 13)}$ 。また，各アクチ ユエータの操作量に対する配向角の変化量から, 初期の制 御ゲインを求めた。

一方, 各アクチュエータを操作したときに, F 面と W 面では逆の挙動を示した。これは，これまでの紙層構造の 形成に関する研究により，ヘッドボックスから吐出するジ エットは厚み方向で速度分布を有することが知られており， フィールドテストにおける J/W 1.01 の条件では，W 面は 押し， $\mathrm{F}$ 面は引きの $\mathrm{J} / \mathrm{W}$ 条件で紙層が形成されていると 仮定すると, 前述の䋊維配向角の形成メカニズムと一致す る。

5.3 制御コンセプト

表 2 はエッジフロー流量及びスライスリップの操作にお ける繊維配向角の挙動についてまとめたものである。操作
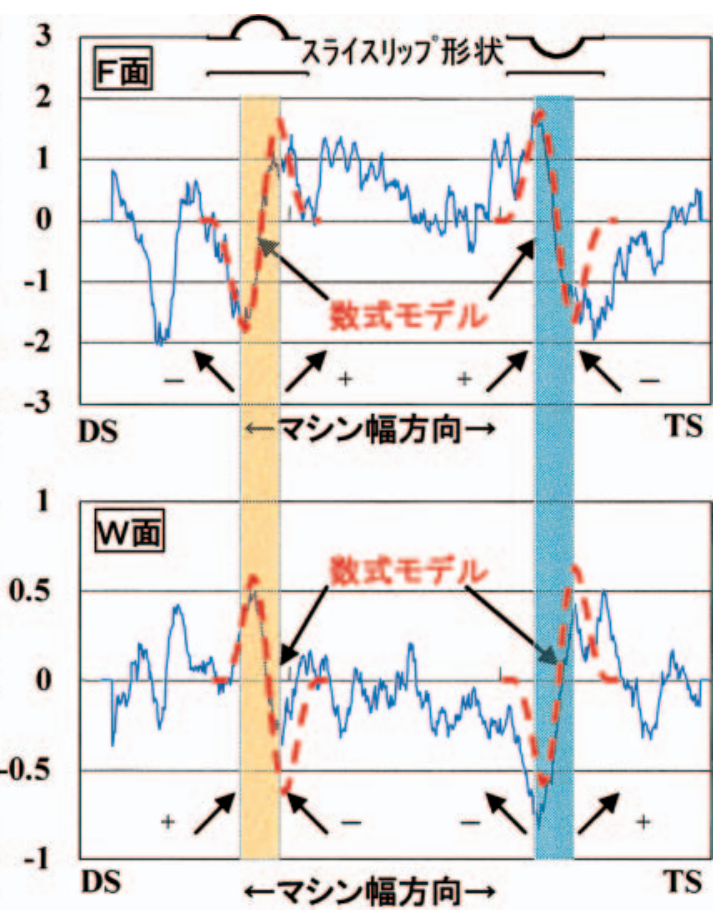

図 7 スライスリップ変化 
側及び駆動側の各エッジフロー流量及びスライスリッププ ロファイルを操作することにより, 全幅にわたって繊維配 向角を制御することが可能である。つまり全体の平均值を エッジフロー流量の操作, 部分的なプロファイルをスライ スリップにより制御する。

ねじれカール改善のためには，ジェットの流れ角度を抄 紙方向と一致させ, $\mathrm{F}$ 面, $\mathrm{W}$ 面の配向角を 0 (従って配向 角差も0）にすることが必要であり，これを制御目標とし た。

\section{6. フィールドテスト}

\section{1 制御テスト 1 ( $\mathrm{F}$ 面配向角 $\left.=0^{\circ}\right)$}

最初にジェットの流れ角度を抄紙方向と一致させるため, 幅方向の速度成分を 0 にすることを目標に F 面配向角を 全幅 $0^{\circ}$ に制御した結果を図 8 に示す。F 面配向角は全幅 でほぼ $0^{\circ} に$ 近づいたが，W 面配向角の操作側端部の角度 が大きく, この部分は制御を行ってもほとんど変化せず表 裏で約 $2^{\circ}$ の配向角差が生じた。また, ねじれカールの実 測においてもこの部分において目標值からわずかに外れる 結果となった。今回, 速度差べクトルを制御に用いたが, マシン端部の $\mathrm{W}$ 面には, 速度差べクトル以外の配向角の 形成要因があると推定された。

6.2 制御テスト2（F-W 面配向角差 $\left.=0^{\circ}\right)$

そこで，表裏の配向角を一致させるため, 配向角差を全 幅 $0^{\circ}$ に設定し制御テストを実施した。図 9 は制御前後に おける配向角差のプロファイルを示したものである。F 面

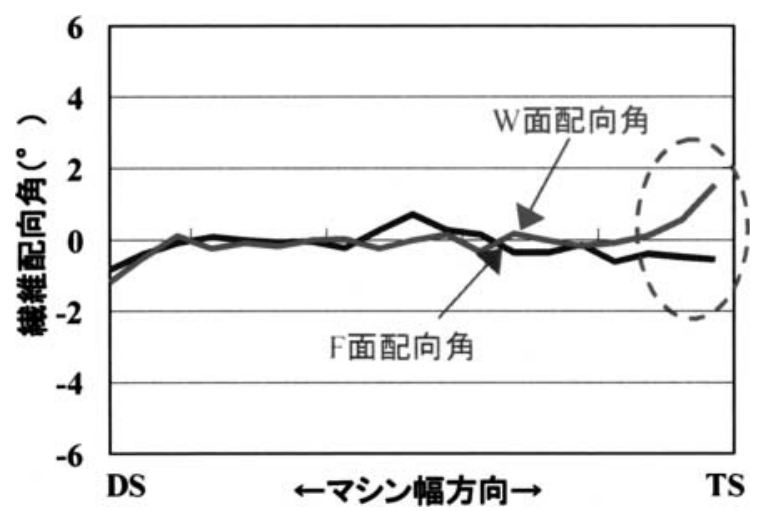

図 $8 \mathrm{~F}$ 面配向角 $0^{\circ}$ での制御結果

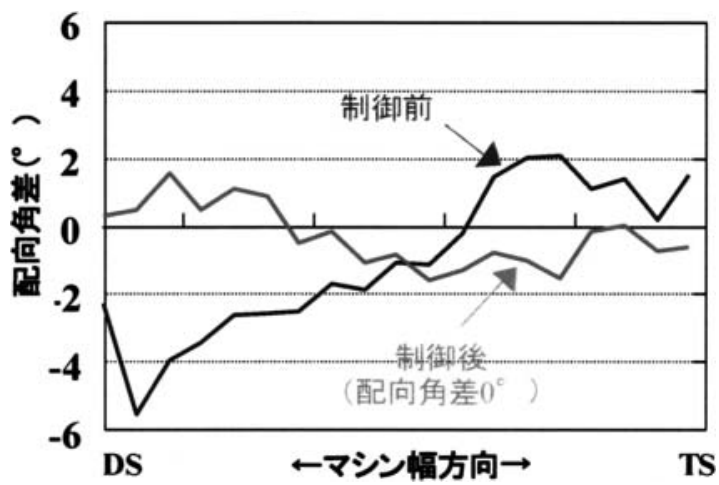

図 9 制御前後の配向角差プロファイル
配向角が $\mathrm{W}$ 面配向角に追従し全幅において，配向角差 $0^{\circ}$ へ収束が見られた。この結果実測におけるねじれカールも 全幅にわたり目標值を達成し（図 10）, 本制御の有効性を 確認することができた。

\section{7. 制御 結果}

図 11 はマシン停機作業からの抄出しから制御開始した 時の繊維配向角のプロファイル変化を示したものである。 制御開始から約 16 分後には, 配向角差プロファイルの $2 \sigma$ が 4.7 から 1.4 まで低下し, 良好な制御となっている。ま た，図 12 は繊維配向角差の制御画面を示したものである。

\section{8. 制御 効果}

本制御の効果として, 配向角差収束性の大幅な向上があ げられる。図13 はマシン停機作業後の抄出しからの配向 角差 $2 \sigma$ の推移を示したものである。従来の熟練オペレー 夕による手動調節の場合には，目標值到達まで $1 \sim 2$ 時間 を要していたのに対し, 自動制御では 30 分以内に目標值 を下回り，その後も安定した状態が維持されている。また， スライス開度を変化することによる坪量プロファイルへの 影響も，非干渉制御により補償し図 14 に示すとおり良好 に制御され，他の紙質に影響を与えることなく配向角だけ を単独に制御することを可能にした。

また，図 15 は図 13 と同様に抄出し後から制御開始し, 収束後に制御 OFF にしたときの配向角差 $2 \sigma$ の推移を示 している。抄出し後は, 原料温度とへッドボックスの温度 差によりスライスリップの全体形状が変化することが知ら れており，この影響で制御 $\mathrm{OFF}$ 直後から配向角差のプロ ファイルが悪化したと考えられた。一方，自動制御を継続 した場合には，プロファイルの悪化は見られず，連続制御 を行うことにより，このような外的要因による配向角差へ の影響についても安定して制御可能であることを確認した。

図 16 は, 各月毎に平均したねじれカール值の推移を示 したものである。2006 年 9 月末からフィールドテストを 開始し，2007 年 2 月から連続制御を使用してきた。自動 制御開始以降明らかにねじれカール值の改善が図られ，平 均值はほぼ半減しており, カール品質向上, 安定化に貢献 している。また，これまで熟練オペレータがその調整に数 時間要していたが, 自動制御によりオペレータの手動介入

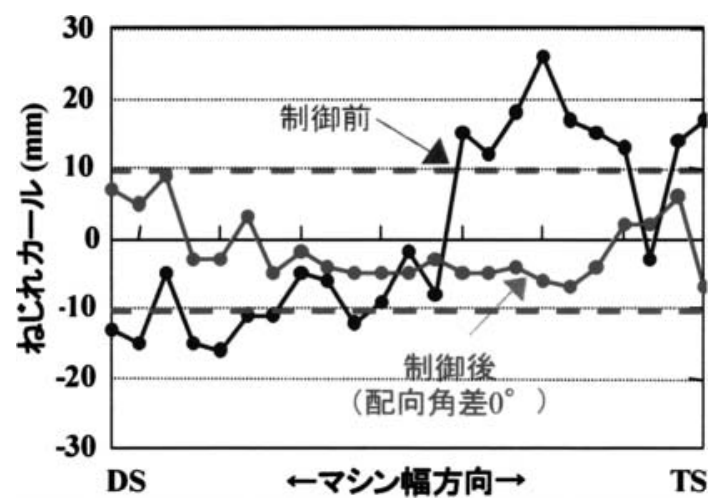

図 10 制御前後のねじれカールプロファイル 


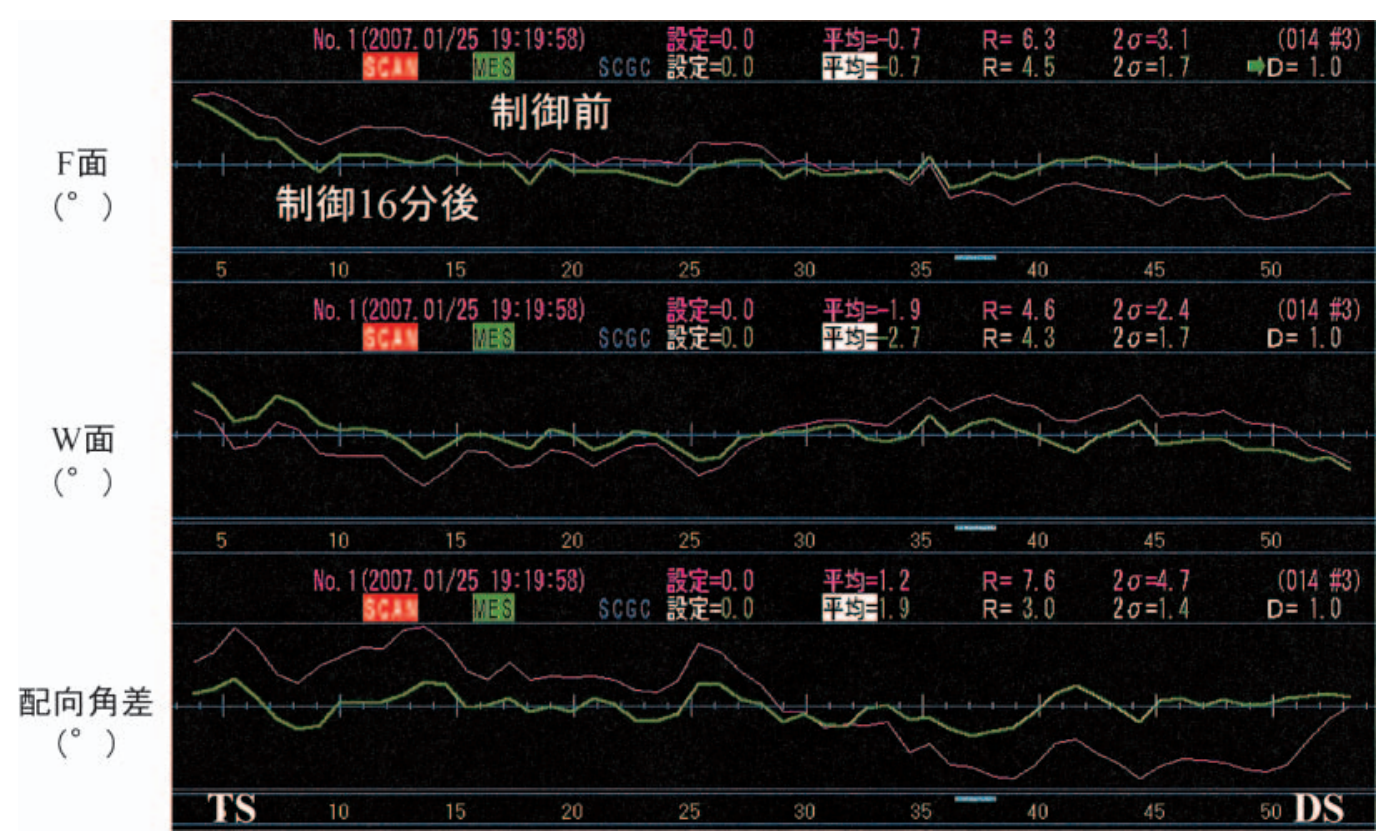

図 11 制御テスト時の配向角プロファイル

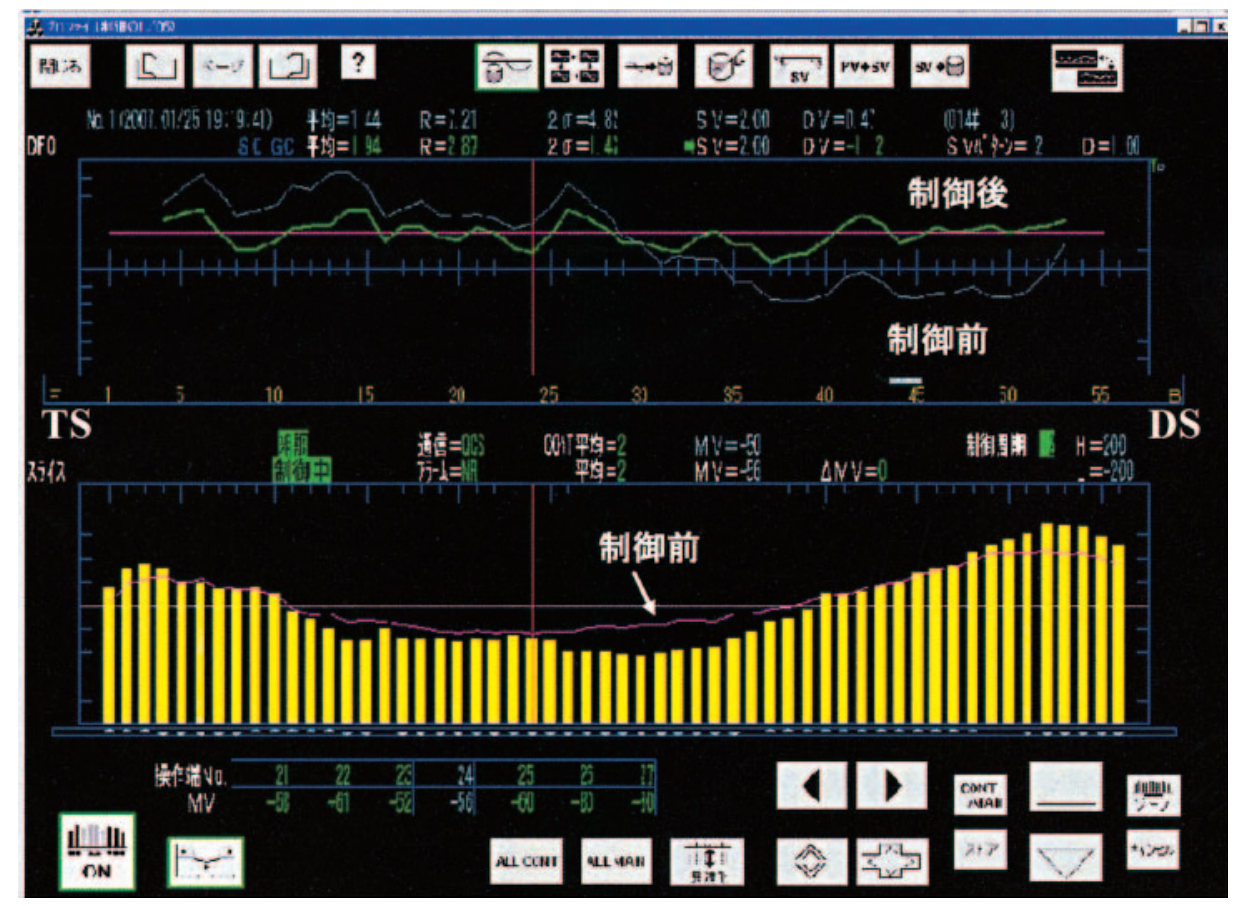

図 12 制御テスト時の配向角差プロファイル制御画面

が不要となったことも特筆すべき点である。

\section{9. おわりに}

オンライン繊維配向計の開発以来, 期待されていた繊維 配向角の自動制御技術の実用化を図ることができた。その 効果は充分満足できるものであり, 収束性, 長期安定性に 非常に優れている。カール品質においては，オペレータに よる手動調整時を上回る結果を得ることができた。
技術を持った熟練オペレータの減少が危惧される中，こ のような自動制御による技術の置換えや補完をすることは, これからの計装技術として重要なテーマの一つと考えてい る。特に今回のような従来に無い新しい技術の開発に際し ては，共同開発メーカはもとより，研究部門，実操業部門， 設備部門等，全関連部門が目標と問題点の共有化を図りな がら, 密接且つ持続的な連携を持って進めることが不可欠 であることも痛感した。 


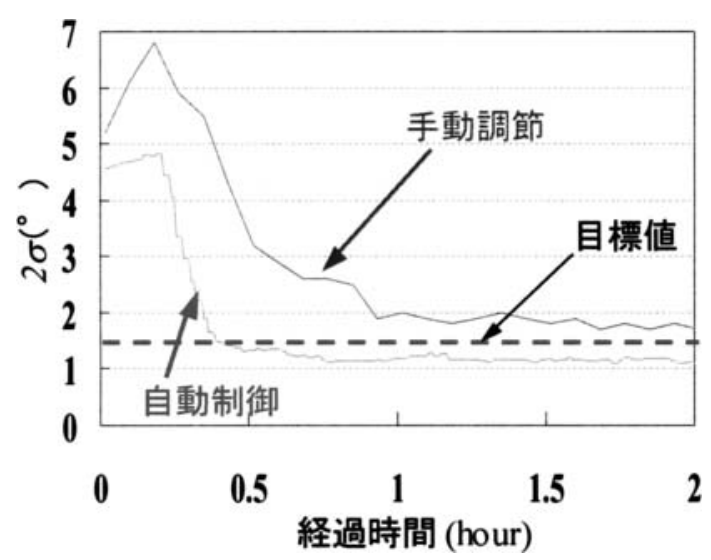

図 13 配向角差 $2 \sigma$ の推移

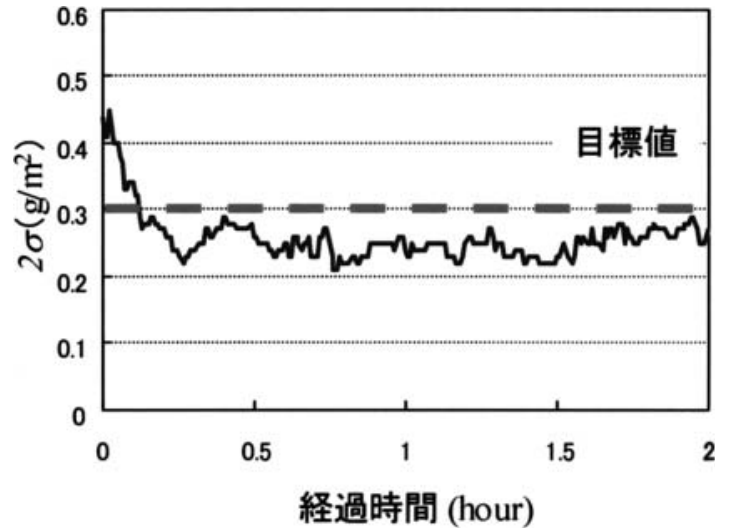

図 14 制御中の坪量 $2 \sigma$ の推移

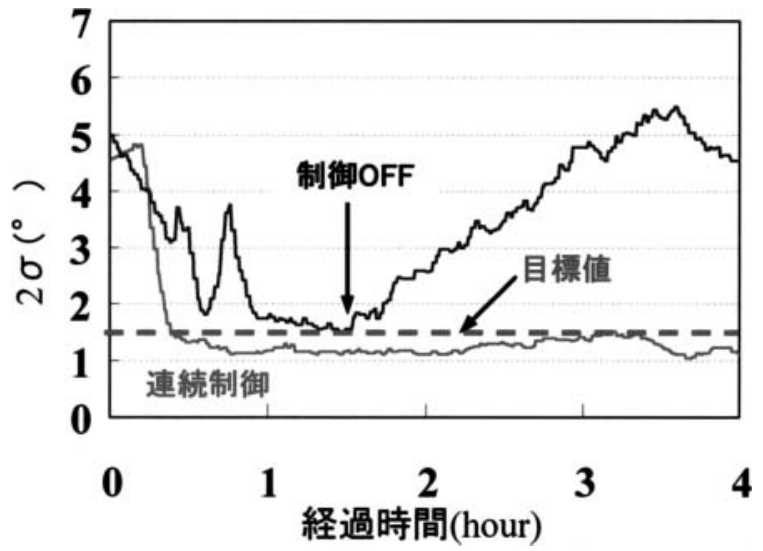

図 15 抄出し後配向角差 $2 \sigma$ 推移

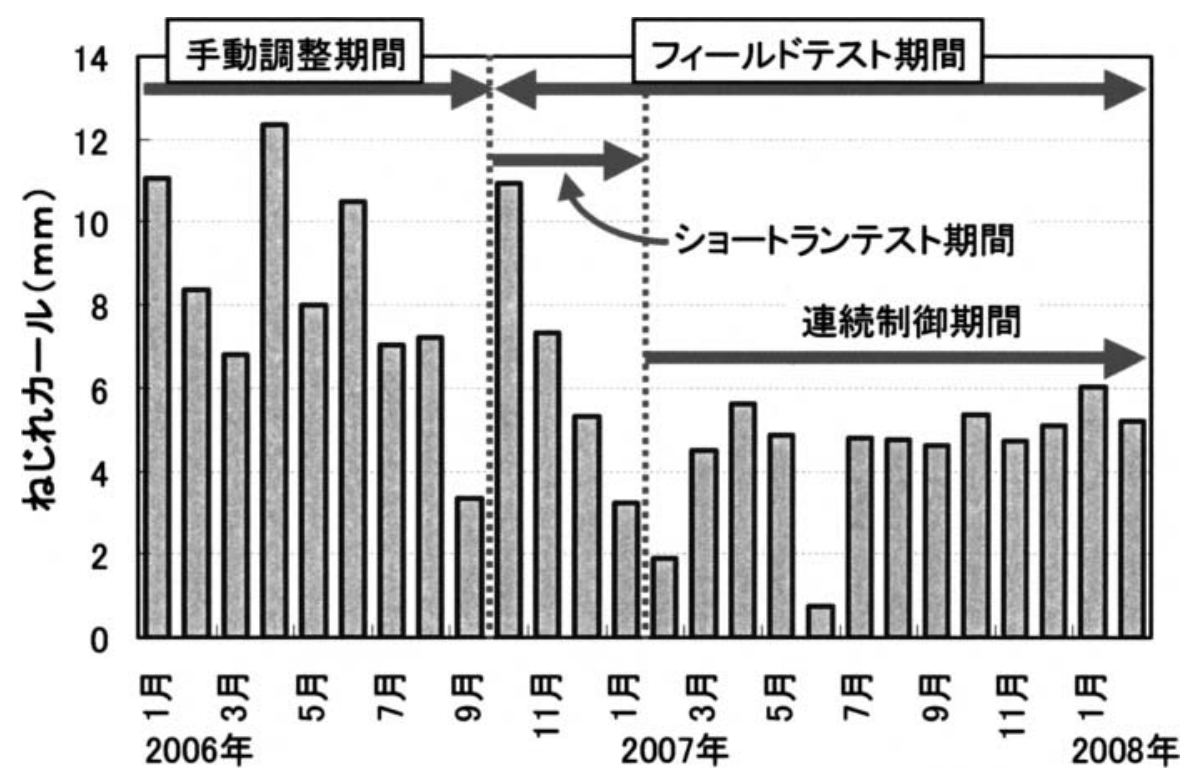

図 16 ねじれカール值の推移

また，繊維配向はこれまでの研究により，PPC 用紙の カール品質の他, 新聞用紙のタワー型オフセット輪転機の 色ずれ，ノンインパクトプリンタ用紙における斜傾等にも 関連があるとされ，今後他マシンへの横展開を図り更なる 製品品質改善につなげていきたい。

最後にメーカとして，この新しい制御技術の共同開発と
実用化に，長期に渡り多大なるご尽力を頂いた横河電機(株) に心から感謝の意を表したい。

\section{References}

1) Nonomura F., Abe Y. and Takeuchi N. : “A Study on the Curling Behavior of Paper Resulting from Heatroller Heating”, 1999 International Paper Physics Confer- 
ence, San Diego, California.

2) Abe Y., Todoroki H., Takeuchi N. and Sakamoto A. : APPITA J., p 625-632 (1996)

3) Hellstrom A. : "The Two Sides of Fiber Orientation", 2005 TAPPI Practical Papermaking Conference, Milwaukee, Wisconsin.

4) Amirthalingam R. : "Curl and Twist Modeling for Monitoring and Control”, Control Systems 2002, Stockholm, Sweden.

5) Fukuoka K., Hatano A., Abe Y. and Takeuchi N.: “Development of On-line System for Measuring Fiber Orientation on Paper Surface”, 2000 TAPPI Engineering Conference, Atlanta, Georgia.

6) Subbarayan R., Tran P. and Chen S. : "Control of Fiber Orientation of a Paper Sheet Using On-line Measurements”, Control Systems 2002, Stockholm, Sweden.

7) Kniivila J. and Nuyan S. : "Focusing on the Edges of Profile Control”, Control Systems 2004, Quebec City, Canada.
8) Odell M. and Pakarinen P. : “The Compleat Fibre Orientation Control and Effects on Diverse Paper Properties” 2001 Papermakers Conference, Atlanta, Georgia.

9) Chen S. and Hellstrom A. : “Online Measurement and Control of Sheet Dimensional Stability-Twist and Curl”, Control Systems 2006, Tampere, Finland.

10) Abe Y., Todoroki H., Okazaki K., Inadome T. and Sakamoto A. : JAPAN TAPPI J. 47 (7) 17-26 (1993)

11) Yamamoto J., Todoroki T., Ono K., Ochi T., Sasaki T. and Sano, H. : "NewAutomatic Control System for Fiber Orientation and Improvement of the Quality of Copy Paper”, PaperCon '08, Dallas, Texas.

12) Sasaki T., Sano H., Yamamoto J., Todoroki T., Ono K. and Ochi T. : Proceedings of the Control Systems 2008, Vancouver, BC, Canada, p 117-122

13) Sasaki T. and Ono K., et al. (Yokogawa Electric Corporation, Nippon Paper Industries Co., Ltd.) : Patent Number: JP 2008-36375 